

\section{Digitized by the Internet Archive in 2011 with funding from University of Toronto}








\title{
CONTRIBUTIONS OF THE
} ROYAL ONTARIO MUSEUM OF ZOOLOGY

No. 27: VARIATION IN BONASA UMBELLUS, WITH PARTICULAR REFERENCE TO THE SPECIES IN CANADA EAST OF THE ROCKIES By L. L. SNyder and T. M. ShortT

Reprinted from Can. Jour. Res., D., Vol. 24, Aug. 1946

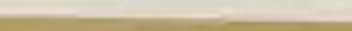

\author{
LOGY
}



VARIATION IN BONASA UMBELLUS, WITH PARTICULAR REFERENGE TO THE SPEGIES IN GANADA EAST OF THE ROGKIES

By L. L. Snyder and T. M. Shortt 


\title{
VARIATION IN BONASA UMBELLUS, WITH PARTICULAR REFERENCE TO THE SPEGIES IN GANADA EAST OF THE ROCKIES ${ }^{1}$
}

\author{
By L. L. SNyder ${ }^{2}$ and T. M. Shortt ${ }^{3}$
}

\begin{abstract}
A study of 624 specimens of Bonasa umbellus shows that variation in the species in eastern North America consists in a loss of red pigment from south to north. Westward in Canada there is a reduction of black resulting in paleness and greyness. This variation resolves itself into eight subspecies, which can be grouped into two "super-subspecies," based on the potential for redness. The ratio of colour phases and "trimming" of most Canadian races has been worked out. The type locality of $B . u$. umbelloides has been determined as Belvedere, Alta. The race canescens of Todd is found valid and the evidence is presented by the application of a simple quantitative tone or value scale. Its range extends from James Bay to central and western Ontario, consequently the range of $B . u$. togata is greatly restricted in Ontario. Minor refinements of the ranges of other races are presented.

The incidence of the red phase is higher in females, the percentages of occurrence suggesting that this phase is a sex-linked recessive character. A variation designated as "copper-trimmed" is more prevalent in males and may be controlled by a dominant sex-linked factor.
\end{abstract}

\section{Introduction}

The collection of ruffed grouse in the Royal Ontario Museum of Zoology has long invited study and classification, but meagre representation of the species from the southern part of its range has been a deterrent. Now, in the light of the thorough revision by Aldrich and Friedmann (1) a satisfactory approach is possible and some contribution to the subject of variation in this species can be made. The Museum's collection consists of 439 skins. Through the kindness of Dr. A. L. Rand an additional 173 skins from the collection of the National Museum of Canada were made available for study. Also, a dozen key specimens representing two western races were loaned by the United States National Museum through Dr. Herbert Friedmann. These bring the total of specimens examined to 624 . The number of specimens that originated from scattered localities in the United States is small but has served to demonstrate the bases for the interpretations of Aldrich and Friedmann. Examination of the extensive Canadian collection largely confirms their work but extends it in some respects.

\section{VARIATION IN Bonasa umbellus}

Plumage variation in Bonasa umbellus is probably as complex as will be found in any species of bird. In addition to distinctive age plumages (natal down, juvenile, and adult) there is moderate sexual dimorphism. (The following sex characters usually hold: the ruff of the male is larger and

1 Manuscript received March 8, 1946.

Contribution No. 27 of the Royal Ontario Museum of Zoology, Toronto, Ont.

2 Curator, Division of Birds, and Assistant Director, Royal Ontario Museum of Zoology.

3 Ornithologist-artist, Division of Birds, Royal Ontario Museum of Zoology. 
displays more metallic colour or sheen; the subterminal band on the tail is complete, not broken on the central pair of feathers as in the female; and the upper breast is crossed by a band of dark feathers, not a mottled or broken pattern of dark spots on a suffusion of warm colour as in the female.) Also, the ruffed grouse is recognized as a classic example of a dichromatic species; as commonly expressed, 'grey' and 'red' phases occur apparently in all populations. Variation is further complicated by the fact that these phases are bridged by graded intermediates. In addition, apparently all populations produce individuals that display erythrism in respect to the ruffs, the dark subterminal band on the tail, usually both, and rarely also involving other markings of the plumage that are usually black. This type of variant, which we shall call 'copper-trimmed', may be of either sex and is associated with both the grey and red phases. Also, anomalous individuals occur, probably in all populations, that do not fall into the categories mentioned and that are markedly unlike the local stock that produced them. Further, it should be mentioned that though specimens may be grouped as to sex and age, and assigned to a particular colour phase, or grade, or type in respect to trimming, no two are precisely alike in detail of pattern, etc. Through all this maze of variation there is differentiation correlated with geographysubspeciation. Racial differences can be appreciated only when large series are examined, atypical specimens eliminated, and corresponding phases compared. To add to this rather prolonged enumeration of the presumed heritable variations in the plumage of the ruffed grouse, it should be mentioned that bleaching and wear affect the colour, tone, and pattern of the plumage, and that differences have been noticed that are attributable to washing skins in the process of preparation. All these factors complicate comparative study.

\section{Procedure in Classification}

Uttal (11) and Aldrich and Friedmann have shown that the extent of feathering on the tarsus of ruffed grouse is correlated with geography. We accept the picture as presented by the recent reviewers in respect to tarsal feathering except that we would include the ruffed grouse of the northeast, which display an intermediate condition, with the western group on the basis of other characters as will be shown later. Also we have found that colour and pattern on the ventral surface of ruffed grouse are greatly variable within a given population, seasonally and otherwise, and therefore only of secondary or supporting value in working out geographic races. Dimensions have not been used in the present study in agreement with the recent revisers who remark "neither dimensions nor proportions.... seem to have any significant geographical variation." Our procedure has been to compare corresponding colour phases of the various populations, largely from a dorsal view. Actually, owing to the excess of grey-phased birds in most Canadian populations, racial differences have been worked out largely with them, redphased specimens being used separately and as supporting evidence. We have segregated specimens into the two phases, grey and red, on the basis 
of the colour of the upper surface of the tail and its coverts. Intermediates have been referred to one phase or the other, thus producing only one arbitrary dividing line. We believe that any selection of a particular phase by collectors of museum specimens would be in favour of the minority phase in a given region. 'This point is important in connection with the tables showing phase ratios that appear in this paper.

\section{Geographic Variation}

In broad terms, geographic variation in the ruffed grouse, in eastern North America, consists of a loss of red pigment from south to north, together with some increase in the amount of black pigment. 'These trends are most obvious when the dorsal areas of specimens in series are viewed and it applies to both the red and grey colour phases of the species. Westward in Canada and thence north and south, east of the Rocky Mountains, variation consists of some reduction of black pigment, without the acquisition of more red, resulting in comparative paleness and greyness as noticed in dorsal view of both colour phases. In other words, east of the Rocky Mountains, the species is warmest in colour in the southeast, with a saturation centre in the lower Appalachians; darkest, or blackest, in the northeastern forest; and greyest in the Great Plains region northward, with the coldest and most nearly bicoloured condition attained in the Yukon and Alaska.

More critically, geographic variation in the ruffed grouse east of the Rocky Mountains resolves itself into eight races, seven of which were recognized by Aldrich and Friedmann. Racial segregation is largely based on the tone or value of the dorsal aspect. If the predominance of colour, i.e., redness or greyness, is considered particularly, it becomes obvious that the species east of the Rockies is divisible into two major units. One is predominantly reddish (in both colour phases), with restricted tarsal feathering and comprises four races, the ranges of which are contiguous and lie in the central-south and southeast; the other is predominantly greyish (in both colour phases), with extensive tarsal feathering and comprises four races, which collectively occupy the north, west, and northwest.

We recognize that racial characteristics are correlated with local environmental conditions. But, in addition, the fact that the eight races can be grouped into two major geographic units and the manner in which these meet suggest that these units represent what might be termed super-subspecies possessing some difference in their potential for the production of redness brought about during a period of isolation in the past. The two groups now meet somewhat abruptly, i.e., there is not an intermediate race occupying intermediate range, one that is difficult to assign to either the reddish or greyish group. Furthermore, no radical change of environment is obvious where the two super-subspecies meet. In view of the fact that the appearance of ruffed grouse of the northeast relates them to grouse of the west, it is suggested that the northeastern population is a penetration from the west not from the south. These observations lead us to postulate that some 
isolation was brought about during the glacial period. With the recession of the Keewatin lobe, the western element with its weak potential for redness moved east and with the disappearance of the Labrador lobe a southeastern element with a strong potential for redness moved north.

Colour and tone characters displayed by ruffed grouse east of the Rocky Mountains and their geographic correlation are closely paralleled in other species. A similar situation has been recorded in connection with the song sparrow (Melospiza melodia) in northeastern North America (Fleming and Snyder (5)) and, to note at least two other cases without giving details, variation in the house wren (Troglodytes aedon) and the horned owl (Bubo virginianus) appear to follow the same trend.

\section{Races of Ruffed Grouse East of the Rockies}

Aldrich and Friedmann have recognized three races of the ruffed grouse in the central-south and southeastern part of North America-the typical form, umbellus, from eastern Pennsylvania to Massachusetts and the District of Columbia; the Appalachian-Ohio valley form, monticola, from southern Georgia to southeastern Michigan and extreme southern Ontario; and the mid-western form, medianus, from Missouri to southern Minnesota and southwestern Michigan. We accept their discrimination, quoting two passages from their paper, which perhaps should be borne in mind: "The height of expression of .... [the characters of monticola] is found among specimens from the mountains of the southern part of the Appalachian Range," and "If this race [medianus] were not separated geographically from Bonasa umbellus umbellus by Bonasa umbellus monticola, its recognition might be questioned. There seems to be less difference between medianus and $u m b e l l u s$ than between any other two subspecies of ruffed grouse herein recognized as distinct."

Because the material used in the present study was largely Canadian in origin, our comments for the most part concern forms occurring north of the international boundary, thus certain races limited in range to areas within the United States receive little treatment in this review. The reader is referred to the work of Aldrich and Friedmann for detailed descriptions. Such descriptive matter as we have introduced is in the form of broad characterizations. Comparisons are made between races of close resemblance, not between each form and the type race as was done by Aldrich and Friedmann.

\section{Bonasa umbellus monticola}

We accept the application of the race name monticola to the ruffed grouse of extreme southern Ontario on the general basis of the recent revision with the comment that specimens from this area closely conform to the detailed description given by the revisers and they are similar to a representative specimen from the most southern part of the range of the form, Hawkins County, Tennessee. As might be expected, certain individuals from southern counties in Ontario do not conform; they are somewhat weaker in chroma 
and resemble available specimens from eastern Pennsylvania, etc. (umbellus) and southern Wisconsin (medianus, as applied by Aldrich and Friedmann, not as described by Todd (10)).

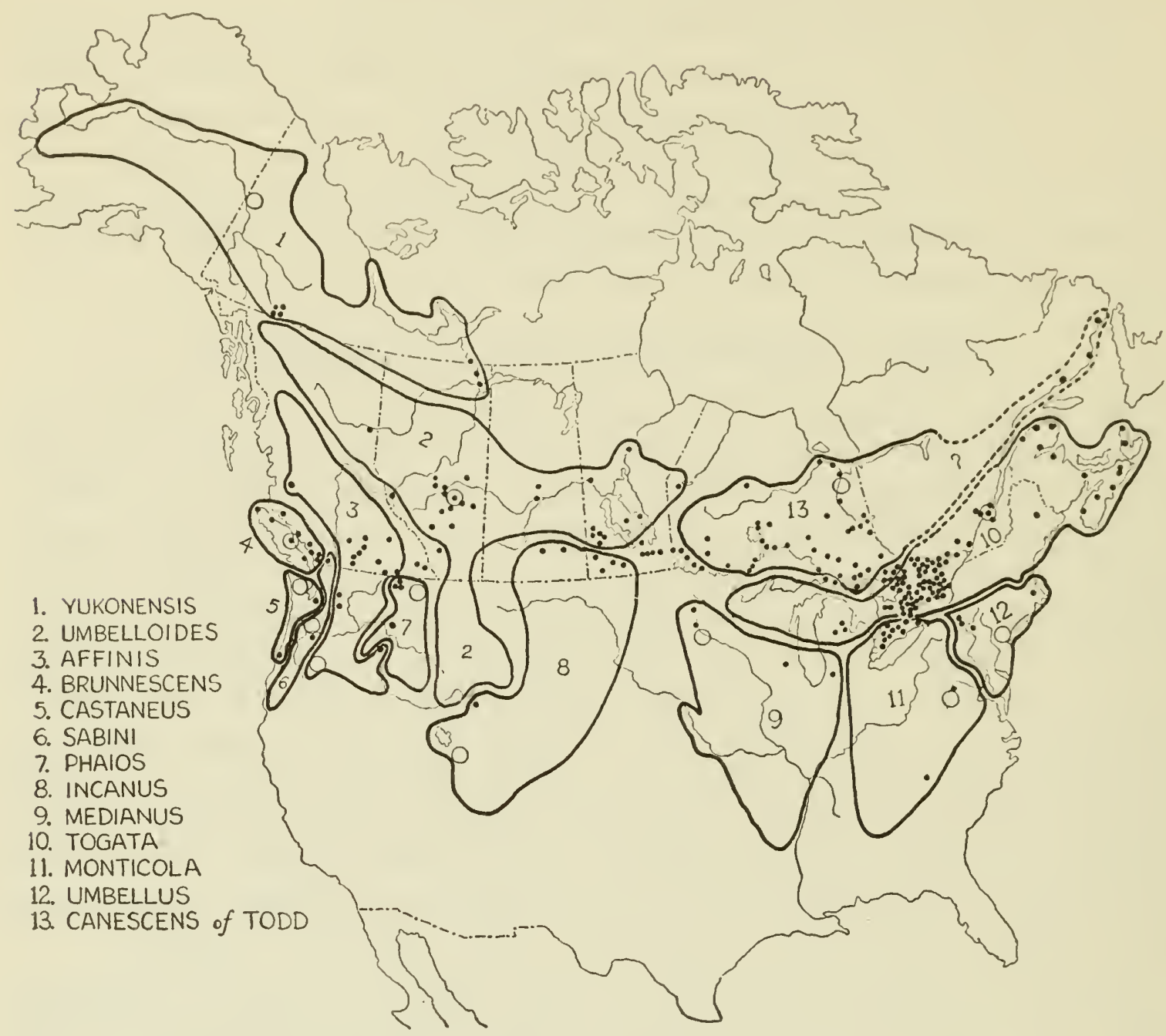

FIG. 1. Distribution of the races of ruffed grouse (Bonasa umbellus). Solid black spots indicate localities from which one or more specimens have been examined by the authors. Circles indicate type localities. The boundary lines of races follow those of Aldrich and Friedmann except where modifications were warranted by the present study: for example, $B$. $u$. canescens of Todd, 13, is distinguished from umbelloides, 2 , but its eastern limits are indicated as uncertain*; the range of $B . u$. umbelloides is correspondingly restricted and slightly modified in the region of the Canadian Rockies; the range of $B . u$. togata, 10, is considerably restricted; and the ranges of B. u. yukonensis, 1, affinis, 3, and castaneus, 5 , slightly extended. The northern limits of range of the species are based on ecological grounds or on known occurrences but disregard certain records considered to be extralimital.

The race is predominantly a red one, a quality that holds for both phases in comparison with ruffed grouse over most of Canada east of the Rocky Mountains. Comparing like phases, its chroma averages stronger than in $B$. u. togata and the tone value in dorsal view averages darker than in umbellus or medianus. According to the series that has been examined, the red phase

* Only three specimens have been seen from the Canadian Labrador region, one incomplete. All were red-phase individuals, plus copper trimming in one case. It is impossible to definitely allocate so few specimens of a minority phase. Actually the evidence they present suggests affinities with populations to the south rather than the west. 
predominates in both sexes, but is more frequent in females (see table below). The feathering on the tarsus is restricted in this form.

Ratio of COLOUR pHases of monticola (34 SPECIMENS)

\begin{tabular}{|c|c|c|c|c|c|c|}
\hline & \multicolumn{3}{|c|}{$\sigma^{7} \sigma^{7}$} & \multicolumn{3}{|c|}{$9 \%$} \\
\hline & $\begin{array}{l}\text { Black- } \\
\text { trimmed }\end{array}$ & $\begin{array}{l}\text { Copper- } \\
\text { trimmed }\end{array}$ & Total & $\begin{array}{l}\text { Black- } \\
\text { trimmed }\end{array}$ & $\begin{array}{l}\text { Copper- } \\
\text { trimmed }\end{array}$ & Total \\
\hline $\begin{array}{l}\text { Red phase } \\
\text { Grey phase }\end{array}$ & $\begin{array}{l}5(23.8 \%) \\
9(42.9 \%)\end{array}$ & $\begin{array}{l}6(28.6 \%) \\
1(4.7 \%)\end{array}$ & $\begin{array}{l}11(52.4 \%) \\
10(47.6 \%)\end{array}$ & $\begin{array}{l}8(61.5 \%) \\
3(23.1 \%)\end{array}$ & $\begin{array}{l}2(15.4 \%) \\
0\end{array}$ & $\begin{array}{r}10(76.9 \%) \\
3(23.1 \%)\end{array}$ \\
\hline Total & $14(66.7 \%)$ & $7(33.3 \%)$ & 21 & $11(84.6 \%)$ & $2(15.4 \%)$ & 13 \\
\hline
\end{tabular}

As pointed out by Aldrich and Friedmann, the grey phase is "very much like that of the brown. [red] phase of togata." With the understanding that colour phase intermediates occur, it can be readily perceived that knowing whence a specimen originated is often essential to its classification.

The range of $B . u$. monticola in Canada is limited to that portion of southern Ontario north of Lake Erie and south of Seaforth in the Lake Huron area, Glen Morris in the Grand River Valley, and Hamilton at the west end of Lake Ontario. Northward and eastward along the north shore of Lake Ontario it merges with B. $u$. togata.

Bonasa umbellus togata

A series of 210 specimens largely from within the belt from Michigan to Nova Scotia has been ample to reveal the character and trace much of the distribution of this form. Eight specimens were from the type locality, the Quebec City region, as designated by Todd (10). This is the most northerly of the predominantly red grouse populations of eastern North America. It has, on the average, appreciably more black pigment in its plumage than other reddish grouse of the east. The reddish colour of the dorsal area of both colour phases tends toward brownish and is comparatively dull, i.e., the chroma is weaker. Also, the feathering on the tarsus is restricted.

In the far eastern portion of the range attributed to togata, the Canadian Maritime Provinces, there is a tendency toward differentiation from what is thought of as typical togata. Our series of 25 unselected specimens shows a trend toward a strengthening of red chroma and some intensification of black. These observations, together with the attenuate range of togata, which is interrupted by the Great Lakes, suggest the interpretation that the population called togata is simply a belt of intermediates. If a coarser grouping of grouse were employed, such as restricting monticola to the southern Appalachians and making medianus a synonym of umbellus, togata might be rejected altogether and grouse occupying this belt considered as intergrades between predominantly reddish grouse of the south and greyish grouse of the north. However, in harmony with fine divisions that can be perceived and have been proposed, we accept togata as a race. 
The race togata, with the exception of the restricted population in the Maritimes, is predominantly grey-phased, as shown in the table below. The Nova Scotia series is excluded from the table and presented separately.

Ratio of Colour phases of togala (185 specimexs exclusive of Nova Scotia)

\begin{tabular}{|c|c|c|c|c|c|c|}
\hline & \multicolumn{3}{|c|}{$\sigma^{x} \sigma^{7}$} & \multicolumn{3}{|c|}{ 우 } \\
\hline & $\begin{array}{l}\text { Black- } \\
\text { trimmed }\end{array}$ & $\begin{array}{l}\text { Copper- } \\
\text { trimmed }\end{array}$ & Total & $\begin{array}{l}\text { Black- } \\
\text { trimmed }\end{array}$ & $\begin{array}{l}\text { Copper- } \\
\text { trimmed }\end{array}$ & Total \\
\hline $\begin{array}{l}\text { Red phase } \\
\text { Grey phase }\end{array}$ & $\begin{array}{l}13(11.9 \%) \\
78(71.6 \%)\end{array}$ & $\begin{array}{c}6(5.5 \%) \\
12(11 \%)\end{array}$ & $\begin{array}{l}19(17.4 \%) \\
90(82.6 \%)\end{array}$ & $\begin{array}{l}24(31.5 \%) \\
48(63.3 \%)\end{array}$ & $\begin{array}{l}3(3.9 \%) \\
1(1.3 \%)\end{array}$ & $\begin{array}{l}27(35.5 \%) \\
49(64.5 \%)\end{array}$ \\
\hline Total & $91(83.5 \%)$ & $18(16.5 \%)$ & 109 & $72(94.7 \%)$ & $4(5.3 \%)$ & 76 \\
\hline
\end{tabular}

Except for the tail colour, which is the determining feature as to phase, the red phase of togata resembles the grey phase of monticola, and the grey phase of togata is similar to the red phase of grey races occurring to the north and west.

Ratio of colour phases of togata (25 Specimens from Nova Scotia)

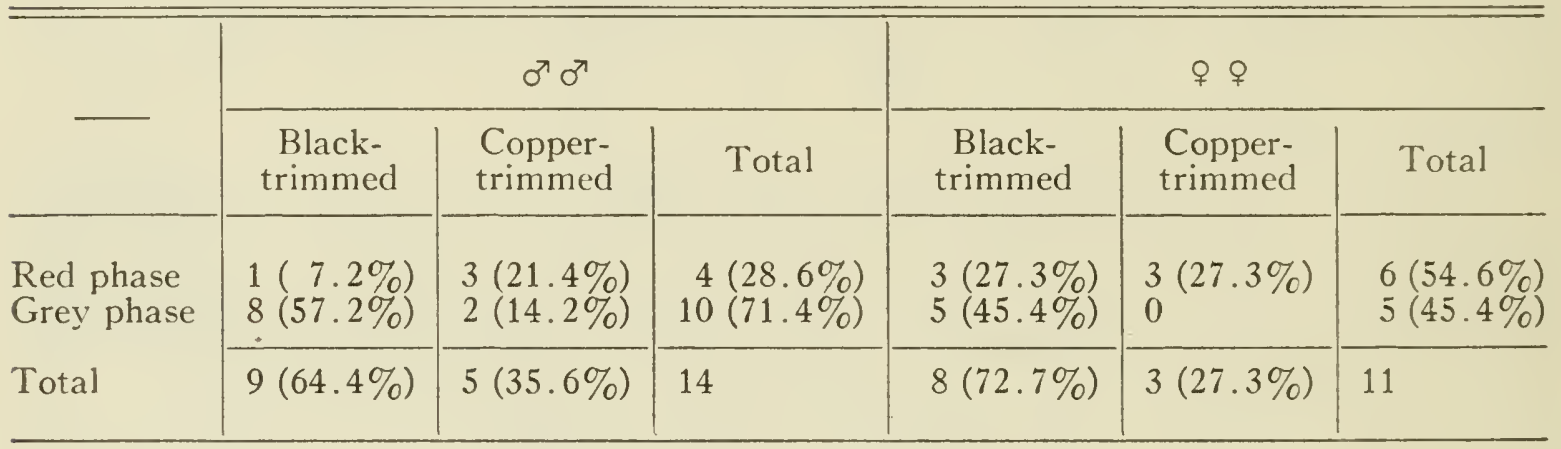

The increased ratio of red-phased and copper-trimmed specimens in the rather small series from the Maritimes has made qualitative comparisons with the whole togata series difficult and probably accounts in part for our observation relative to the strengthening of red chroma. An attempt to demonstrate distinctness quantitatively (other than by phase and trim ratio, see tables above) disclosed no significant difference. There is a tendency among Nova Scotia grouse, particularly from coastal areas, to exhibit some intensification and extension of black in the bars on the sides and flanks and in the spots on the distal tail coverts. Also there is a tendency for the oval, grey spots on the rump to be larger than on typical togata. With these observations we are inclined to regard this population as representing an incipient race and to agree with Todd (10) in rejecting thayeri of Bangs (2). The differences between it and typical togata are no greater than have been noticed in several very local populations.

In the matter of local variation it should be pointed out that we have observed that there can be a change of type in a precise locality after a lapse 
of some years. For example, a series of seven grey-phased, unwashed, and apparently 'unfoxed', autumn specimens in the Royal Ontario Museum, taken by Mr. J. A. Munro in the vicinity of Coboconk, Victoria County, Ont., in 1910, matches topotypic specimens of togata. Another unselected series of five grey-phased, unwashed, autumn specimens, collected in the vicinity of Coboconk between 1933 and 1940 by Mr. John Edmonds, are decidedly grey, approaching closely the ruffed grouse of central and northern Ontario. Such a change, one that appears to veer toward an adjacent race, could be brought about by alteration of the genetic constitution of a population, an accident that might readily be favoured by periodic die-off. Or, if the area concerned were marginal, reduction or destruction of the habitat on one side only might farour the ascendancy of the type occupying the other side. In the present case we know that man has markedly reduced grouse habitat to the south whence reddish elements might infiltrate, while to the north, where grey elements are known, the region is relatively undisturbed.

Some modification of the range of $B$. $u$. togata from that presented by Aldrich and Friedmann is necessary. We have no reason to alter the southern limits of the race as determined by them but find that the range is restricted markedly in the Ontario area. Although what appears to be togata (or medianus?) influence can be traced sporadically into extreme western Ontario from Minnesota, conceivably as far as Lac Seul and Lake Nipigon, the range of togata does not encircle Lake Superior. (The northeast shore of Lake Superior and contiguous areas are occupied by a distinct, dark race to be considered later in this paper.) The northern limits of range in Quebec are not known.

\section{Bonasa umbellus incanus}

The recognition of this race in Canada depends somewhat upon the limits of variation ascribed to the form. There is no doubt that occasional specimens from extreme southern Saskatchewan and Manitoba can be referred to incanus and tendencies toward it are evident as far as Indian Head, Sask.; Shoal Lake, Vivian, and Winnipeg, Man.; and Minnesota (precise locality not indicated). In fact, a specimen from Rainy River District, Ont., is virtually identical with a representative specimen of incanus from central Wyoming. However, other birds from the Rainy River region are dark and quite unlike the specimen in question. The race incanus possesses an extensively feathered tarsus and is predominantly grey, paler than average umbelloides, and warmer than yukonensis. Even the red phase is referred to as 'ashy' by Aldrich and Friedmann, and probably the grey predominates over the red phase although we have insufficient material to check the point. There is some evidence for the interpretation that incanus influence extends northward in the Canadian prairies and tends to broaden the limits of variation of ruffed grouse that must be designated under the name umbelloides, or that the name incanus should be treated as a synonym of umbelloides. 


\section{Bonasa umbellus umbelloides}

Confusion has occurred as to the exact application of the name umbelloides owing to an inexact designation of the type locality. Todd (10) proposed to "consider the Ruffed Grouse taken at Henry House, Alberta, as virtual topotypes of umbelloides." Aldrich and Friedmann (1) follow and designate Henry House as the restricted type locality. We have been able to trace the course and activities of Douglas, the original collector and describer of the form, and can now indicate the type locality precisely.

Reference to the Journal Kept By David Douglas During II is Travels in North America, 1823-1827 (8) has revealed where the type pair of $B . u$. umbelloides was collected. The portion of this very interesting volume, of importance here, begins with his journey homeward with the so-called "annual express" across the continent. The point of departure was Fort Vancouver (on the Columbia River, near the present city of Portland, Ore.). The day of departure was Mar. 20, 1827. Among the company making this journey was Mr. Edward Ermatinger, who was travelling to Hudson's Bay. Ermatinger's York Factory Express Journal (4) has also been consulted since it includes a map of the route, and indicates thereon place names of the period.

They ascended the Columbia to the big bend in British Columbia. Here they started the climb over the crest of the Rockies afoot, following the banks of the Wood River. The arduous climb took them through Athabaska Pass on May 2nd. Up to this point in the journal frequent mention is made of "grouse" and "partridge" and "pheasants." In some instances Latin names are included, but there is some uncertainty as to species and sexes involved. However, the first reference that definitely indicates the ruffed grouse (Bonasa) occurs under date of May 3rd when they were approaching Rocky Mountain House (now Jasper). Here are his words: "Fired at a cock bird, of a light grey with a black ruffle and top like the common woodpheasant [fur trade name for ruffed grouse] but I think different; unfortunately he escaped, although I brought him to the ground. Saw two hens afterwards, which I took to be the same species." These were obviously novelties to Douglas, but as noted he did not secure specimens. Douglas had previously taken B. . sabini in the vicinity of Fort Vancouver, Clarke County, Washington (7) and he had had experience with the species in Pennsylvania.

On May 13th Douglas and other members of the party arrived at Fort Assiniboine, now in Alberta. Under that date he records that "Mr. Stuart killed a male partridge, the same species that I saw in the bosom of the mountains, called by him White Flesher-different from the common ruffled grouse - too much destroyed for preserving." And Douglas adds the following note as if speaking to himself- "Make some small slug and procure a pair of this fine bird."

On May 14th they took their course-- "in a south direction . . . . [actually southeastward] and camped five miles from the [Athabaska] River." The 
next day (May 15th) he went at daylight in quest of partridge. "Killed a pair of White Fleshers and a hen of a different species. The male a beautiful bird. Only one of the three, the hen of the White Flesher, was worth skinning. Had eggs-small, pure white, about the size of the common pigeon. Pine leaves, and leaves of birch in the crop. The flesh is remarkably white. The breastbone uncommonly high and very short, differs only from the male in the ruffle being less conspicuous as to colour and size."

On May 18th the party arrived at "Eagle Lake" (Lac la Nonne). In Douglas' journal for the next day (May 19th) he states, "In my walk round part of the lake in wood killed a pair of White Fleshers, male and female. The former being a fine bird, and having time on my hands, I preserved it." This male, together with the female secured on May 14th, provided Douglas with the "pair" which he had determined to secure (see remark under date of May 13th). The type locality of umbelloides is therefore from Lac la Nonne northwestward to within five miles of the Athabaska River, a linear span of about fifty miles. We here restrict it to Lac la Nonne (Belvedere, Alta.).

Since the original description of umbelloides (Douglas (3) ) is not long, it is here transcribed in full:

"T. umbellus. Perhaps no one of the genus extends over such a tract of country, and no one is more varied in plumage than the present bird. In the valleys of the Rocky Mountains, $54^{\circ}$ north latitude, and a few miles northwards near the sources of Peace River, a supposed variety of this species is found-different from $T$. umbellus of Wilson. On comparing my specimens from that country with some which I prepared in the States of New York and Pennsylvania, and on the shores on the chain of lakes in Upper Canada, I find the following differences. First, the northern bird is constantly onethird smaller, of a very light speckled mixed gray, having little of that rusty colour so conspicuous in the southern bird: secondly, the ruffle consists invariably of only 20 feathers, these short, black, and with but little azure glossiness; and the crest-feathers are few and short. Should these characters hereafter be considered of sufficient importance for constituting a distinct species, it might perhaps be well to call it T. umbelloides."

It will be noted that Douglas states that "the northern bird . . . . having little of the rusty colour so conspicuous in the southern bird: . . . " The statement allows for our observation that umbelloides is characteristically a grey but warm race. We have had available six topotypic specimens from Lac la Nonne.

This race can be broadly characterized as essentially a grey one, medium grey, but warm in colour and with the feathering on the tarsus extensive. It is perceptibly suffused with buffy on the pale markings of the back, wing coverts, and secondaries, and also on the ventral surface. It is warmer in colour and averages darker than yukonensis, darker than incanus, and paler than the population that occurs to the east in Canada. It has a more contrasting ('speckled') dorsal pattern than affinis, a race found west of the Rockies. 
Aldrich and Friedmann (1) applied the name umbelloides to all the grouse across Canada from the Rocky Mountains (and according to their map, also the west slope of the Rockies in British Columbia) to the Canadian Labrador. In doing so, they rejected the grey grouse described under the name canescens (Todd (10)) the range of which was designated by the describer as "from Labrador (?) west to James Bay and thence to eastern Manitoba." 'Their remarks were that "although specimens from northern Ontario and middle Quebec average slightly darker ... . than typical umbelloides from the east slopes of the Canadian Rockies, the difference seems to be too slight to recognize as a distinct subspecies." It would seem that this conclusion was warranted in view of the northerly distribution of their Quebec and Ontario specimens. With representative specimens from these areas available to us, amplified by good series from localities immediately to the south where the race attains the height of its expression, we distinguish two forms across Canada, restricting the name umbelloides to the ruffed grouse occupying the region from the east slope of the Rockies (not in British Columbia) eastward in Canada to Ontario. The ratio of colour phases in umbelloides is shown in the following table:

Ratio of COLOUR PHASES of umbelloides (88 SPECIMENS From the Rockies to ONitario)

\begin{tabular}{|c|c|c|c|c|c|c|}
\hline & \multicolumn{3}{|c|}{$0^{x} 0^{x}$} & \multicolumn{3}{|c|}{ \% } \\
\hline & $\begin{array}{l}\text { Black- } \\
\text { trimmed }\end{array}$ & $\begin{array}{l}\text { Copper- } \\
\text { trimmed }\end{array}$ & Total & $\begin{array}{l}\text { Black- } \\
\text { trimmed }\end{array}$ & $\begin{array}{l}\text { Copper- } \\
\text { trimmed }\end{array}$ & Total \\
\hline $\begin{array}{l}\text { Red phase } \\
\text { Grey phase }\end{array}$ & $\begin{array}{l}11(20.4 \%) \\
32(59.3 \%)\end{array}$ & $\begin{array}{l}2(3.7 \%) \\
9(16.6 \%)\end{array}$ & $\begin{array}{l}13(24.1 \%) \\
41(75.9 \%)\end{array}$ & $\begin{array}{l}10(29.4 \%) \\
19(55.9 \%)\end{array}$ & $\begin{array}{l}1(2.9 \%) \\
4(11.8 \%)\end{array}$ & $\begin{array}{l}11(32.3 \%) \\
23(67.7 \%)\end{array}$ \\
\hline Total & $43(79.7 \%)$ & $11(20.3 \%)$ & 54 & $29(85.3 \%)$ & $5(14.7 \%)$ & 34 \\
\hline
\end{tabular}

We accept the pattern of range of the race umbelloides as presented by Aldrich and Friedmann (except the British Columbia portion) from the eastern slopes of the Rocky Mountains across the Prairie Provinces, but we place its limits in northwestern Ontario (Favourable Lake). In southeastern Manitoba, western Ontario (Rainy River and the southwestern part of Kenora District), east to Lake Nipigon, and south to northern Minnesota, some confusion is encountered. It is suggested that this region is the hub of a wheel where admixtures of several races occur.

\section{Bonasa umbellus canescens of Todd}

In a report on birds collected at Lake Abitibi (9) it was noted that the ruffed grouse of the region were "extremely dark dorsally, only part of which can be attributed to wear." Subsequently other material from the central and northern part of the province was secured, which essentially agreed with this observation. In central Ontario, from Lake Nipigon northeastward to Lake Abitibi and south to Sudbury, a population distinct from umbelloides prevails. How far this race ranges eastward is indefinite but certainly it 
reaches central Quebec. The name that can be applied to the form for purposes of this paper is canescens of Todd (10). Todd chose his type from latitude $50^{\circ} 53^{\prime} \mathrm{N}$. on the Abitibi River, Ont., not from central Ontario where the form is most pronouncedly distinct from umbelloides.

In order to test the validity of canescens of Todd and reveal the degree of its distinctness from umbelloides, we have applied a simple quantitative scale. A selection was made of five specimens of ruffed grouse, showing five barely perceptible grades from the palest to the darkest in general dorsal aspect. These graded samples represented localities from Favourable Lake and Lake Nipigon, Ont., to James Bay and Quebec. A similar set of five grades was selected from birds originating in Canada from the Rocky Mountains in Alberta to Favourable Lake, Ont. These two five-grade samples were then matched, and found not to overlap by two grades, thus giving seven grades for the cross-Canada series. Every grey-phased adult specimen from the region concerned in the Royal Ontario Museum of Zoology collection was thereafter matched and placed in its proper grade. The resulting table given below has been referred to Dr. J. W. MacArthur of the University of Toronto who suggested the inclusion of standard error calculations.

SCALE of tone or VAlue showing Distinctness of umbelloides AND canescens of TODD

\begin{tabular}{l|r|r|r|r|r|r|r|r}
\hline \hline \multicolumn{1}{c|}{ Grade } & Pale & & & & & Dark & Mean grade \\
\cline { 2 - 4 } & 1 & 2 & 3 & 4 & 5 & 6 & 7 & \\
$\begin{array}{l}\text { canescens of Todd } \\
\text { umbelloides }\end{array}$ & 13 & 8 & 3 & 1 & 1 & & & $1.81 \pm .20$ \\
\hline Difference & & & & & & & & $3.14 \pm .29$ \\
\hline
\end{tabular}

It is obvious from the table that two distinct populations are involved. $B$. $u$. canescens of Todd, though predominantly a greyish race (not of the reddish southern group), is consistently darker than umbelloides, a large majority of specimens being as dark as the exceptional specimens of the prairie race, and $25 \%$ of canescens specimens are darker than any found in the umbelloides population. None attains the paleness exhibited by $80 \%$ of umbelloides. The tarsal feathering of canescens of Todd is extensive though it represents the most restricted of the well-feathered, greyish races.

Aldrich and Friedmann have pointed out that the name canescens has been used [by Sparrman for a hazel grouse] under the genus Bonasa. Consequently a new name must be applied to the dark race, cancscens of Todd, a matter that awaits the pleasure of the original describer.

Remarks. It is of interest and of considerable importance to comment on the variety of conclusions that have been reached by different workers using partially or entirely different collections bearing on the application of the name umbelloides and on the validity of the form canescens of Todd. Both 
RATIO OF COlour phases of canescens of Tond (50 specimexs)

\begin{tabular}{|c|c|c|c|c|c|c|}
\hline & \multicolumn{3}{|c|}{$\sigma^{x} \sigma^{x}$} & \multicolumn{3}{|c|}{ ㅇ } \\
\hline & $\begin{array}{l}\text { Black- } \\
\text { trimmed }\end{array}$ & $\begin{array}{l}\text { Copper- } \\
\text { trimmed }\end{array}$ & Total & $\begin{array}{l}\text { Black- } \\
\text { trimmed }\end{array}$ & $\begin{array}{l}\text { Copper- } \\
\text { trimmed }\end{array}$ & Total \\
\hline $\begin{array}{l}\text { Red phase } \\
\text { Grey phase }\end{array}$ & $\begin{aligned} 3 & (10.4 \%) \\
20 & (69 \%)\end{aligned}$ & $\begin{array}{l}1(3.4 \%) \\
5(17.2 \%)\end{array}$ & $\begin{array}{r}4(13.8 \%) \\
25(86.2 \%)\end{array}$ & $\begin{array}{r}7(33.3 \%) \\
13(61.9 \%)\end{array}$ & $\begin{array}{l}0 \\
1\end{array}$ & $\begin{array}{r}7(33.3 \%) \\
14(66.7 \%)\end{array}$ \\
\hline Total & $23(79.4 \%)$ & $6(20.6 \%)$ & 29 & $20(95.2 \%)$ & $1 \quad(4.8 \%)$ & 21 \\
\hline
\end{tabular}

Todd and Aldrich and Friedmann used specimens from the east slope of the Rocky Mountains (Henry House) as typical of umbelloides. Todd regarded the eastern Canadian population (Abitibi River, etc.) as paler than typical umbelloides. Aldrich and Friedmann, using the same or partly the same material, regarded the eastern population as slightly darker than typical umbelloides, but not worthy of nomenclatorial recognition. The writers being obliged to use typical specimens from slightly further east (Lac la Nonne) find ourselves in agreement with Aldrich and Friedmann that the eastern population is darker than umbelloides, but we consider the form worthy of a name.

The reasons for these discrepancies are not all clear. Most certainly we should expect some differences in interpretation by different workers using different collections and dealing with inconstant and fine distinctions. Probably the explanation lies in the observation that grouse along the eastern slopes and valleys of the Rockies (Henry House) average slightly darker than those on the prairies (Lac la Nonne) and that specimens from far northern Ontario frequently exhibit a paleness not characteristic of those from central Ontario. This paleness is not sufficiently common or pronounced as to debar the application of the name canescens of Todd to the latter population. Incidentally we have noted a marked similarity in dorsal aspect between canescens of Todd and Idaho and Washington specimens of phaios. However, ventrally phaios is more profusely and intensely barred.

\section{Bonasa umbellus yukonensis}

Only 23 specimens were available for examination, but these were sufficient to characterize the form $B . u$. yukonensis. It is predominantly a pale, grey subspecies, the coldest in colour of all races. Little or no buffy colour invades the whitish markings of the dorsal area. The black markings on the tail are relatively narrow, and light and dark markings on the sides of the head show in rather sharp contrast, not being blended by a wash of warm colour. B. $u$. yukonensis possesses an extensively feathered tarsus.

Because of the small representation of yukonensis no table of the phases is presented. However, adding 11 specimens reported by Grinnell (6) to our series (total, 34), five $(14.7 \%)$ are red-phased and $29(85.3 \%)$ are grey-phased.

We accept the distribution of the form as presented by Aldrich and Friedmann. 


\section{Races of Ruffed Grouse West of the Rockies}

\section{Bonasa umbellus affinis}

With 29 specimens of this form from the province of British Columbia, three from Washington, and one from Oregon available for study, we have not found affinis outstandingly variable in Canada. Aldrich and Friedmann have pointed out that considerable variability is displayed by it in the more arid interior of Washington and Oregon.

B. u. affinis in Canada is predominantly a grey-phased race. It is relatively drab in colour, with little contrast in the dorsal view, not characteristically 'speckled' as is umbelloides. The pattern on the tail is fine and lacks strong contrast.

Two specimens representing this race have been identified from Stuie, B.C., thus extending its range westward to near the coast. Further, the form is recognized at Cranbrook and Fernie in southeastern British Columbia, though two specimens out of seven from the former place approach phaios in appearance. It would seem possible, on the basis of our comparisons between 27 specimens from interior British Columbia and four specimens from central Washington and Oregon, that the northern population may be racially separable from that of the south. British Columbia specimens are more drab and not as warm in colour.

\section{Bonasa umbellus sabini}

We have identified a specimen of $B . u$ sabini, from Sumas, B.C., which record contributes slightly to an understanding of the range of this form in Canada, but does not alter the pattern of distribution as presented by Aldrich and Friedmann.

\section{Bonasa umbellus brunnescens}

With a series of 16 specimens of $B$. u. brunnescens available for study, we find no disagreement with the details presented by the recent reviewers. A not altogether unexpected irregularity concerns a brunnescens-like specimen from Chilliwack, B.C. which is out of the range delineated for brunnescens.

\section{Bonasa umbellus castaneus}

With respect to the race $B . u$. castaneus, we can contribute one point of information relative to its distribution. A specimen from Florence, Ore., in the Royal Ontario Museum of Zoology collection, is undoubtedly a representative of this subspecies. This extends the range to the coastal area of Oregon south of the Columbia River, a point suspected by Aldrich and Friedmann.

\section{Bonasa umbellus phaios}

Our only basis for including this race among Canadian races is that two specimens out of seven from Cranbrook, B.C., approach the form closely. Aldrich and Friedmann have already indicated the possibility of phaios extending into Canada. 


\section{The Red Colour Phase and Sex}

The following table employs all of our data bearing on the frequency of red and grey phases correlated with sex in Bonasa umbellus, east of the Rockies. We have tabulated the data for the two super-subspecies separately since some slight geographic variation is thus revealed. The predominantly grey super-subspecies includes specimens of umbelloides, canescens of Todd, yukonensis, and incanus in diminishing numbers as listed. The red supersubspecies includes togata, monticola, umbellus, and medianus, likewise in diminishing numbers in the order given.

\begin{tabular}{l|c|c|c}
\hline \hline & $\begin{array}{c}\text { Number } \\
\text { examined }\end{array}$ & $\begin{array}{c}\text { Number } \\
\text { red-phased }\end{array}$ & $\begin{array}{c}\text { Red-phased, } \\
\%\end{array}$ \\
\cline { 2 - 4 } Males & 106 & 21 & 19.8 \\
Grey super-subspecies & 144 & 34 & 23.6 \\
Red super-subspecies & 250 & 55 & $22.0 \pm 2.6$ \\
Total & 75 & 26 & 34.6 \\
Females & 100 & 43 & 43.0 \\
Grey super-subspecies & 175 & 69 & $39.4 \pm 3.7$ \\
Red super-subspecies & & & \\
Total & &
\end{tabular}

As shown in the table, the percentage of females displaying the red colour phase $(39.4 \pm 3.7 \%)$ is nearly twice that of males $(22.0 \pm 2.6 \%)$. This difference, $17.4 \%$, is more than three times as great as its standard error, \pm 4.5 , and therefore is considered to be significant. According to Dr. J. W. MacArthur "until breeding tests can be made the red phase of the ruffed grouse might tentatively be regarded as, like 'gold' in the domestic fowl, a sex-linked recessive character, the controlling red factor $(r)$ occurring in roughly $40 \%$ of sex cells."

\section{Copper Trimming and Sex}

The table given below shows the frequency of occurrence of copper trimming in the two sexes for all the full plumage specimens examined representing the two super-subspecies east of the Rockies.

\begin{tabular}{|c|c|c|c|}
\hline- & $\begin{array}{l}\text { Number } \\
\text { examined }\end{array}$ & $\begin{array}{c}\text { Number } \\
\text { copper-trimmed }\end{array}$ & $\begin{array}{c}\text { Copper-trimmed, } \\
\%\end{array}$ \\
\hline $\begin{array}{l}\text { Males } \\
\text { Grey super-subspecies } \\
\text { Red super-subspecies }\end{array}$ & $\begin{array}{l}106 \\
144\end{array}$ & $\begin{array}{l}20 \\
30\end{array}$ & $\begin{array}{l}18.9 \\
20.8\end{array}$ \\
\hline Total & 250 & 50 & $20.0 \pm 2.5$ \\
\hline $\begin{array}{l}\text { Females } \\
\text { Grey super-subspecies } \\
\text { Red super-subspecies }\end{array}$ & $\begin{array}{r}75 \\
100\end{array}$ & $\begin{array}{l}6 \\
9\end{array}$ & $\begin{array}{l}8.0 \\
9.0\end{array}$ \\
\hline Total & 175 & 15 & $8.6 \pm 2.1$ \\
\hline
\end{tabular}


A comparison of the total percentages of males $(20.0 \pm 2.5 \%)$ and females $(S .6 \pm 2.1 \%)$ shows a difference of $11.4 \%$, which is more than three times as great as its standard error, \pm 3.3 , and is therefore considered to be significant. Dr. MacArthur suggests that "the sex incidence could be explained statistically if copper-trimming were controlled by a dominant sex-linked factor $(C)$, the frequency of which is about $10 \%$ of the population. Naturally, such a working hypothesis requires test by experimental breeding."

\section{References}

1. Aldrich, J. II and Friedmans, H. A revision of the ruffed grouse. Condor, 45:85103. $19+3$.

2. Baxgs, O. A new subspecies of the ruffed grouse. Auk, $29: 378-379.1912$.

3. Dotglas, D. Observations on some species of the genus Tetrao and Ortyx, natives of North America; with descriptions of four new species of the former and two of the latter. Trans. Linnean Soc. London, $16: 133-149.1829$.

4. Ermativger, C. O. and White, J. Edward Ermatinger's York Factory express journal, being a record of journey's made between Fort Vancouver and Hudson Bay in the years 1S27-1828. Trans. Roy. Soc. Can. (Ser. 3) 6 (II) : 67-132. 1912.

5. Fleming, J. H. and Snyder, L. L. On Melospiza melodia in Ontario. Occasional Papers, Roy. Ontario Museum Zool., No. 5. 1939.

6. Grinsell, J. A new ruffed grouse from the Yukon Valley. Condor, 18:166-167. 1916.

7. HALL, F. S. Studies in the history of ornithology in the State of Washington (17921932) with special reference to the discovery of new species (Part III). Murrelet, $15: 10-11.1934$.

8. Royal Horticultural Society. Journal kept by David Douglas during his travels in North America, 1823-1827. William IVestley and Son, London. 1914.

9. SNyder, L. L. A faunal investigation of the Lake Abitibi region, Ontario. Univ. Toronto Studies, Biol. Ser. $32: 1-47.1928$.

10. Todd, W. E. C. Eastern races of the ruffed grouse. Auk, $57: 390-397.1940$.

11. UtTAL, L. J. Tarsal feathering of ruffed grouse. Auk, $58: 74-79.1941$. 





\section{ROYAL ONTARIO MUSEUM OF ZOOLOGY}

This series contains reports of Museum studies, including faunal surveys. Except where otherwise stated the price is twenty-five cents a copy.

1. A Faunal Survey of the Lake Nipigon Region, Ontario, by J. R. Dymond, L. L. Sny'der and E. B. S. Logier. 58 pages (out of print).

2. A Faunal Survey of the Lake Abitibi Region, Ontario, by the staff of the Royal Ontario Museum of Zoology. 46 pages.

3. A Faunal Investigation of King Township, York County, Ontario, by L. L. Snyder and E. B. S. Logier. 42 pages (out of print).

4. A Faunal Investigation of Long Point and Vicinity, Norfolk County, Ontario, by L. L. Snyder and E. B. S. Logier. 120 pages (out of print).

5. Some Account of the Amphibians and Reptiles of British Columbia, by E. B. S. Logier. 26 pages.

6. A Study of the Sharp-tailed Grouse, by L. L. Snyder. 66 pages (out of print).

7. The Passenger Pigeon in Ontario, by Margaret H. Mitchell. Records of the history of the now extinct wild pigeon (Ectopistes migratorius) in Ontario. Paper, \$1.00. Cloth, \$1.50. 181 pages.

8. The Distribution of Breeding Birds in Ontario, by James L. Baillie, Jr., and Paul Harrington. 134 pages (out of print).

9. Some Freshwater Fishes of British Columbia, by J. R. Dymond. 14 pages.

10. The Birds of the Lake St. Martin Region, Manitoba, by T. M. Shortt and Sam Waller. 51 pages.

11. Baird's Sparrow, by B. W. Cartwright, T. M. Shortt and R. D. Harris. 44 pages.

12. Ontario and its Avifauna, by L. L. Snyder, and The Museum's Bird Collection, by J. L. Baillie. 14 pages.

13. Birds of Algonquin Provincial Park, Ontario, by D. A. MacLulich. 47 pages (out of print).

14. A Faunal Investigation of Western Rainy River District, Ontario, by L. L. Snyder. 57 pages.

15. The Fishes of the Ottawa Region, by J. R. Dymond. 43 pages.

16. The Birds of the Vicinity of Lake Nipissing, Ontario, by W. E. Ricker and C. H. D. Clarke. 25 pages.

17. The Summer Birds of Yakutat Bay, Alaska, by T. M. Shortt. 30 pages.

18. History of the Royal Ontario Museum of Zoology, by J. R. Dymond. 52 pages (out of print).

19. A Faunal Investigation of Prince Edward County, Ontario, by L. L. Snyder, E. B. S. Logier, T. B. Kurata, F. A. Urquhart, and J. F. Brimley. 123 pages.

20. The Blattaria and Orthoptera of Essex County, Ontario, by F. A. Urquhart. 32 pages.

21. A Faunal Investigation of the Sault Ste. Marie Region, Ontario, by L. L. Snyder, E. B. S. Logier and T. B. Kurata. 68 pages.

22. Some Recent Bird Records from Canada's Eastern Arctic, by T. M. Shortt and H. S. Peters. 11 pages.

23. The Summer Birds of the Northeast Shore of Lake Superior, Ontario, by J. L. Baillie, Jr. and C. E. Hope. 27 pages.

24. The Coregonine Fishes of Northwestern Canada, by J. R. Dymond. 61 pages.

25. Some Considerations on the Distribution of Fishes in Ontario by Isobel Radforth. 116 pages.

26. Charles Fothergill (1782-1840) by James L. Baillie, Jr. 21 pages (out of print).

27. Variation in Bonasa umbellus, with Particular Reference to the Species in Canada East of the Rockies, by L. L. Snyder and T. M. Shortt. 16 pages. 



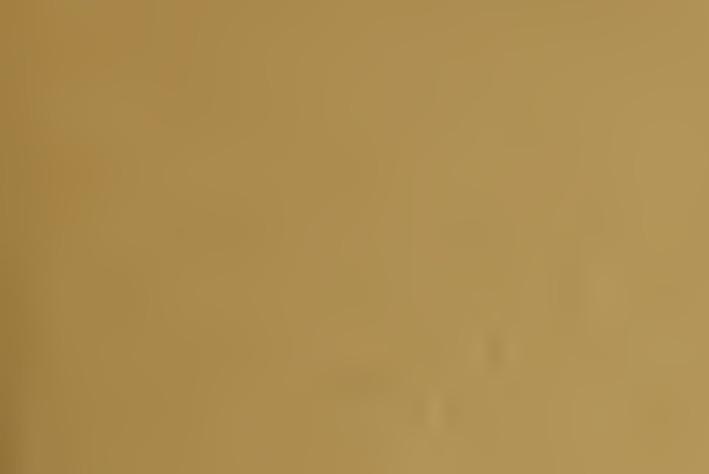

ans
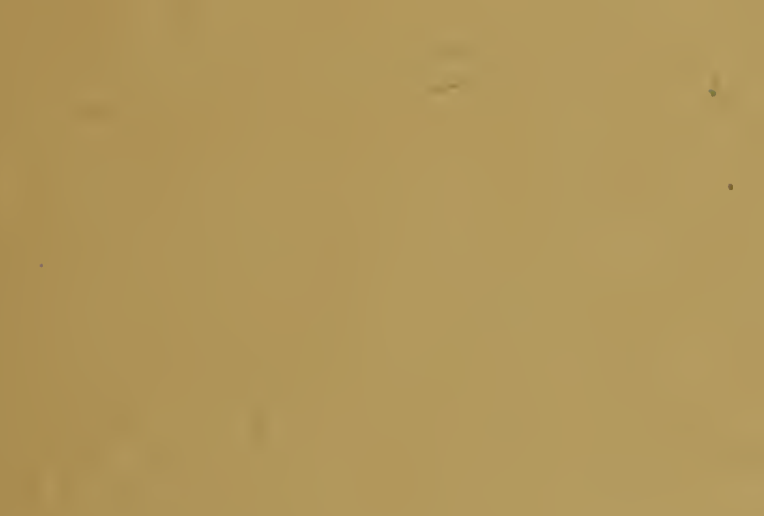

I.

to

$y=$ 
241
2083

1

$-120$ 



